Guasch, O. (comp.) (2012). Vidas de hombre(s). Barcelona, Bellaterra.

\title{
Vidas de hombre(s)
}

Jordi Caïs

Universitat de Barcelona

Tal como comenta Oscar Guasch en el prefacio de Vidas de hombre(s): "el género ya no es lo que era. Ha cambiado". A esa afirmación yo añadiría: "Es cierto, ha cambiado tanto que ahora incluso se investiga a los varones". Y es que tradicionalmente las preguntas de investigación en estudios de género se han referido a las mujeres y gran parte de la investigación ha sido realizada por mujeres. El feminismo contemporáneo ha sido uno de los impulsores más importantes de esta área de estudios, por lo que no es de extrañar que sean las mujeres las que se hayan encargado de dar visibilidad a los problemas de género tanto en ámbitos académicos como en los diferentes foros sociales. Sin embargo, los esfuerzos para revelar las dinámicas de género centradas en las mujeres también han visibilizado, de rebote, la masculinidad y sus problemas. Tradicionalmente, las características masculinas se han presentado como fijas e inamovibles. Eran la norma, la referencia o - utilizando un concepto más sociológico- el tipo ideal sobre el que se anclaban los estudios sobre mujeres. Pero, si la masculinidad se define en contraste con la feminidad, el estudio riguroso de la masculinidad también es relevante para entender el orden y las dinámicas de género. Aunque en un volumen mucho menor si se compara con la feminidad, en el mundo académico anglosajón ya hace un par de décadas que se realizan estudios en que se reconocen diferentes masculinidades y se investigan sus orígenes, estructuras y dinámicas. En España este tipo de estudios son aún más recientes y escasos. Y en este contexto, el estudio Vidas de hombre(s) resulta valioso e incluso imprescindible porque da los primeros pasos para llenar un vacío académico.

Las transformaciones de la modernidad han conllevado una revisión de un modelo de masculinidad tenido por referencial e intocable. El paso a la denominada "modernidad tardía" ha sido acelerado y la adaptación está siendo difícil. Las instituciones sociales dejan de ser referencias sólidas e inamovibles que actúan como guías de comportamiento social. Las referencias sociales no 
desaparecen, pero ahora son laxas y cambiantes. Los cambios culturales influyen en la concepción de las relaciones de poder dentro de la pareja. La asignación de roles está cambiando de manera acelerada. Cada vez hay más familias donde ambos cónyuges tienen un trabajo remunerado. ${ }^{1} \mathrm{Y}$ en el momento en que la mujer se incorpora al mercado laboral en las mismas condiciones que su pareja, la definición tradicional de los roles conyugales en función del género pierde legitimidad. El reparto de responsabilidades, derechos y obligaciones familiares de cada uno de los cónyuges pasa a ser objeto de negociación entre las partes. Este cambio de modelo familiar que conlleva la negociación de los roles de los miembros de la familia lleva a que se hable de la aparición del concepto de familia negociadora de roles y actividades. El concepto de masculinidad hegemónica ha quedado atrapado en las redes de la modernidad tardía; o quizá sería más gráfico argumentar que se ha ahogado en la modernidad líquida de Zigmunt Bauman.

En la modernidad, la identidad era una categoría de pertenencia que se daba por supuesta. La adscripción identitaria estaba determinada por categorías heterorreferenciadas como el género o la clase social que no eran mutables con facilidad. Hoy en día vivimos en un mundo lleno de oportunidades en el que todo permanece incompleto y la identidad es un proyecto que no termina nunca. La identidad es plural y abierta. En la modernidad tardía no existen los proyectos acabados, por lo que el individuo está abocado a una constante reconstitución de sí mismo. En este entorno, hablar de masculinidad hegemónica o de crisis de la masculinidad resulta anticuado, incluso se antoja ridículo. Ese varón hegemónico e inmune al estigma social presentado por Erving Goffman el año 1963 en su obra Stigma and Social Identity como "joven, casado, blanco, urbano, heterosexual, padre protestante de educación universitaria, empleado a tiempo completo, de buen aspecto, peso y altura y con un récord reciente en deportes" cada vez tiene menos sentido en el contexto de la modernidad tardía. El concepto de masculinidad enmarcada en una concepción heteronormativa de género que dualiza y simplifica las diferencias de género en las categorías de mujer y varón ignorando diferencias o exclusiones dentro de cada una de las dos categorías ya no resulta útil. Incluso la reformulación del concepto de masculinidad hegemónica que R. W. Connell y James W. Messerschmidt hicie-

1. Los datos más recientes del INE indican que en el $61 \%$ de familias españolas con parejas con edades comprendidas entre los 25 y los 49 años los dos cónyuges trabajan. 
ron en 2005 para adaptar el concepto a los cambios de la modernidad tardía dotándolo de una reformulación teórica más rica y cuidada parece insuficiente. Leyendo el libro Vidas de hombre(s) uno piensa que, inevitablemente, la trayectoria a largo plazo de los estudios de género conllevará la deconstrucción y desaparición del propio concepto de género.

Vidas de hombre(s) es un libro de relatos de vida. En él se presentan 11 relatos autobiográficos, escritos por los propios protagonistas, en los que estos explican sus vidas, pensadas y expresadas en clave de género, como hombres. Los autores de los relatos utilizan sus experiencias vitales para revisar de manera crítica las formas vigentes de ser hombre y explicar lo que la masculinidad o más bien las masculinidades representan para ellos. El libro, coordinado por el sociólogo Oscar Guasch, se presenta como si incluyera vidas de "hombres cualquiera" - de hecho, Guasch juega con ese concepto para calificar y clasificar a los hombres que participan en el libro-. Sin embargo, los autores que participan en la compilación distan mucho de ser "hombres cualquiera”. El relato que abre la compilación es obra de uno de los fundadores del MHX= (Movimiento de Hombres por la Igualdad) y el relato que cierra el libro es obra de un destacado miembro de la segunda generación de hombres igualitarios. El texto también incluye tres doctores en Ciencias Sociales y varios profesores universitarios, además de psiquiatras y enfermeros en ejercicio. Es decir, no se trata de cualquier clase de varones, sino de un tipo de hombres a quienes se supone capacidad reflexiva. Si a ello se añade que casi la mitad de los coautores son varones de-generados (por cuanto homosexuales o gays), se obtiene un cuadro que dista mucho de la supuesta "normalidad" masculina (entendida en clave sociológica) con que Guasch pretende presentar a estos varones.

Los varones escogidos por Oscar Guasch no son una muestra representativa, pero sí son una muestra adecuada porque todos los participantes son hombres para los que el género es algo visible e importante en sus vidas. Tal como argumenta Guasch en la introducción del libro, la literatura sobre masculinidades insiste en que el género es invisible para los hombres como la pobreza para las personas solventes o las barreras arquitectónicas para los válidos. Pero al leer los relatos se observa que el género cada vez es más visible para los varones y, además, en muchos casos provoca sufrimiento. Bastantes relatos del libro, especialmente los de los varones gays, explican experiencias tristes y duras. La construcción de la identidad de género hace sufrir, incluso en una 
sociedad donde la identidad personal se reconstruye continuamente. Hoy en día las personas aún sufren más redefiniendo el género que la clase o el estatus social. Definir y redefinir el género sigue siendo un juego de expectativas y control social. Incluso R. W. Connell y James W. Messerschmidt, en su reformulación del concepto de masculinidad hegemónica, deben admitir que, en el marco de la identidad tardía, el propio modelo hegemónico de masculinidad ya no siempre es ventajoso, sino que también genera insatisfacciones a los varones no disidentes $y$, en entornos sociales tan cambiantes como los actuales, a veces también les hace sufrir.

El libro forma parte de la colección, dirigida por Olga Viñuales, "Relatos de vida", de Edicions Bellaterra, en la que se pretende que las personas dejen testimonio de sus experiencias vitales compartiendo subjetividades con los lectores. En Vidas de hombres(s) Guasch opta por pedir un relato en primera persona al informante y presentarlo en su totalidad con la mínima intervención del investigador. Guasch opta por dejar que sean ellos mismos quienes escriban con sus propias palabras; cada texto "contiene su propio universo". El control del investigador es mínimo y no se produce la interacción propia de la entrevista en profundidad. El compilador selecciona a los sujetos de forma estratégica para que sean una muestra con unas características (nivel de estudios, profesión) que permitan construir por ellas mismas un relato comprensible y bien articulado. Son relatos escritos en primera persona en los que el relator escoge el momento y el sitio adecuados para trasladar sus experiencias a un posible lector. Los once relatos se presentan bajo un título escogido por el mismo sujeto, quien intenta definir el contenido del relato. Esta es una excelente estrategia a la que recurre el investigador para presentar de forma amena cada uno de los relatos y facilitar al lector el punto de partida bajo el que debe empezar a leerlos.

Oscar Guasch comenta, en la introducción de Vidas de hombre(s), que "es un libro basado en el conocimiento que parte de la experiencia y el análisis teórico queda en segundo plano". Es una afirmación sorprendente puesto que el libro aporta evidencias importantes que ayudan a reformular los marcos teóricos de género y masculinidades. Los relatos del libro permiten observar que es difícil hablar de identidad o de identidades masculinas. Los relatos indican que la identidad es fluida y situacional, que las personas negocian su identidad de género, con frecuencia, diversas veces a lo largo de su vida. Cuando nos referimos a la identidad masculina no podemos pensar en "un tipo" o en "diferentes tipos" de 
varones. Las tipologías no son útiles en este caso. La identidad masculina es la manera como los hombres se posicionan ellos mismos a partir de las prácticas discursivas. Esta evidencia es la mayor aportación de este libro. Aunque de lo que no hay duda es de que el libro consiste también en una suerte de proyecto político que busca difundir el ideario de los hombres igualitarios y, a la vez, visibilizar las diferencias intramasculinas. Parece claro, tras leer este texto, que el mito sexista (arraigado en el feminismo más añejo) que afirma que todos los hombres son iguales no se sostiene por ningún modo. 